\title{
CULTURE STUDIES DALAM NOVEL TARIAN BUMI KARYA OKA RUSMINI
}

\section{Florensia Carliani Mbues}

Program studi Pendidikan Bahasa Indonesia, Fakultas Ilmu Sosial dan Humaniora, Universitas PGRI Adi Buana Surabaya

Charlinmbues17@gmail.com

Eko Cahyo Prawoto

Dosen Program Studi Pendidikan Bahasa Indonesia, Fakultas Ilmu Sosial dan Humaniora, Universitas PGRI Adi Buana Surabaya ecahyop@gmail.com

\begin{abstract}
This study aims to examine the existing culture in the novel Tarian Bumi. In conducting this research the researcher used a qualitative descriptive method. Qualitative method means that the resulting data the form of words in the form of quotations. The main data source in this study came from Oka Rusmini's Novel Cultural Studies in the Earth Dance Novel. The data obtained in this study used reading techniques, note-taking techniques and literature study techniques with steps to read carefully, directed, thoroughly and understand after that were analyzed. In this cultural study, there are 3 values contained, which are the focus of research on the novel Tarian Bumi, the first is the value of belief. This belief value exists and is highly depicted in the novel Tarian Bumi. The value of belief in the novel Tarian Bumi is described in three relationships, namely Intrapersonal (the relationship between oneself), Interpersonal (the relationship between other people and the environment) and Transpersonal (a relationship that cannot be seen from a relationship with divinity which is the highest power). Second, Moral values. The moral values described in the novel Tarian Bumi can seen the actions or behavior of characters in the Tarian Bumi novel. The three values of Customs. The values of these customs are seen to be very attached to the traditional Balinese Hindu rituals and all kinds of rules that exist in the Brahmana and Sudra aristocrats.
\end{abstract}

Keywords: novel, qualitative methods, cultural values.

\section{PENDAHULUAN}

Karya sastra merupakan bentuk penyampaian gagasan dan penyampaian manusia menggunakan bahasa sebagai media penyampaiannya. Sesuai dengan teori sastra menurut Semi (2008:2), sastra merupakan karya seni kreatif yang berupa media memiliki dua tujuan pokok. Pertama, menyapaikan ide, teori, emosi, sistem berpikir, dan pengalaman keindahan manusia. Dalam masyarakat sastra dipandang sebagai hasil imajinasi pengarang serta refleksi terhadap gejala-gejala sosial disekitarnya. Menurut Wellek (2014:3) sastra merupakan kegiatan kreatif yang menghasilkan sebuah karya yang bernilai seni. Artinya sastra dapat menjadi wadah untuk menyampaikan gagasan, perasaan yang melihat berbagai macam gejala sosial dalam masyarakat sehingga menjdikan sebuah karya dari hasil imajinasi maupun refleksi.

Karya sastra terbagi atas tiga bagian, yaitu puisi, prosa dan drama. Salah satu prosa baru adalah novel 
dan cerpen. Novel merupakan cerita yang jauh lebih panjang dan luas dari cerpen, yang dikemas dalam berbagai kisah seperti percintaan, persahabatan, perjuangan dan lainlain. Sesuai dengan pengertian novel dalam KBBI (2008:969), novel merupakan karangan prosa yang panjang mengandung rangkaian cerita kehidupan seseorang dengan orang disekelilingnya dengan menonjolkan watak dan sifat masing-masing orang.

Novel tidak hanya sebagai sarana penghibur tetapi juga salah satu pembentuk karakter pembaca. Novel dapat dijadikan pedoman dalam kehidupan sosial karena banyak cerita dalam novel yang mencerminkan aspek kehidupan dalam masyarakat dan novel juga dapat memberi pesan-pesan moral lewat konflik atau masalah yang terjadi dalam cerita. Masalah-masalah yang digambarkan dalam novel bukan hanya tentang kehidupan masyarakat atau gejala-gejala sosial yang terjadi tetapi novel juga sering kali menggambarkan bagaimana keadaan lingkungan dari suatu masyarakat yang ada didalam cerita novel tersebut. Selain gejala sosial dan lingkungan, novel juga kerapkali mengangkat tentang perkembangan dan aspek budaya dalam masyarakat. Hal ini tentu sangat menarik, novel mampu membuat kita berimajinasi dan novel juga banyak memberi kita pengetahuan tentang sebuah budaya, adat istiadat yang terkandung dalam masyarakat dan kerapkali terjadi sama persis dalam kehidupan sehari-hari.

Hal menarik tersebut yang membuat novel sering dijadikan objek penelitian. Kajian atau teori yang digunakan peneliti juga sangat bervariasi seperti femenisme, psikologi, sosiologi, culture studies (studi budaya) dan masih banyak lainnya. Secara spesifik kali ini akan mengkaji menggunakaan teori/pendekatan culture studies (studi budaya).

Culture studies merupakan salah satu pendekatan baru yang mengkaji karya sastra dan culture studies digunakan untuk mengkaji tentang budaya. Sebagai pendekatan yang belum banyak ditulis dalam literatur karya sastra di Indonesia tentu menimbulkan sejumlah pertanyaan mengenai bentuk pendekatan ini. Diantaranya, apa itu teori culture studies, bagaimana culture studies ini diaplikasikan, apa yang menjadi poin penting dalam culture studies dan bagi mana kemunculan dan perkembangannya. Jawaban dari pertanyaa-pertanyaan itu akan dipaparkan pada tulisan ini meski tidak menjawab secara menyeluruh. Ada banyak pengertian culture studies yang dipaparkan oleh para ahli, contohnya yang dipaparkan Akhyar Yusuf Lubis. Akhyar Yususf Lubis mendefenisikan culture dalam enam poin, tetapi disini secara singkat saya hanya memaparkan dua saja dari enam defenisi Akhyar tersebut. Menurut Akhyar Yusuf Lubis adalah: (1) Cultural Studies mengkaji budaya dalam konteks sosial-budaya; (2) Cultural Studies tidak sembarangan nilai dan melibatkan diri dengan nilai, pertimbangan moral masyarakat serta konstruksi sosial dan tindakan politik.

Dari dua pengertian tersebut, secara praktis dapat disimpulkan bahwa culture studies merupakan ilmu yang mengkaji budaya dan jelas memberi nilai moral baik dalam konteks sosial-budaya maupun politik yang tidak terlepas dari kehidupan bermasyarakat. Sejalan dengan itu maka, pada penelitian ini akan menggunakan teori dari Tylor. 
Menurut Tylor, kebuduyaan merupakan segala aktivitas manusia, yang meliputi pengetahuan, kepercayaan, moral, seni, hukum, adat-istiadat, dan kebiasaankebiasaan. Pengertian yang senada dengan Tylor, sekaligus memberikan peran terhadap masyarakat, diberikan oleh Marvin Harris (1999:19), yaitu aspek kehidupan manusia secara keseluruhan dalam masyarakat, yang didapatkan dengan cara belajar, baik belajar tentang tingkah laku maupun pikiran.

Pada dasarnya sastra dan kebudayaanlah yang menjadi poin utama dan dasar dalam membentuk culture studies. Penjelasan istilah sastra dan kebudayaan, sastra sebagai studi kultural, perlu diberikan agak luas dengan pertimbangan, disatu pihak, studi kultural adalah ilmu yang relatif baru, khususnya studi kultural yang dikembangkan oleh mazhab Inggris, belum banyak dikenal atau diketahui oleh masyarakat luas, bahkan oleh masyarakat akademis.

Seperti yang telah dijelaskan diawal, penelitian ini menggunakan teori dari Tylor yakni culture studies mengkaji tentang budaya. Secara spesifik dijelaskan bhawa budaya yang menjadi objek kajian budaya adalah teks dan kehidupan seharihari. Dengan demikian objek kajian budaya biasa mencakup budaya populer yang mungkin tidak dianggap bernilai seni tinggi, bahkan merupakan salah satu proyek terpenting dalam kajian budaya adalah mengkaji budaya populer.

Culture studies dipilih sebagai teori yang cocok untuk kajian budaya. Yang memperkuat kajian ini juga tentunya dukungan banyak refrensi yang sangat membantu mendefenisikan dan menjelaskan secara luas tentang teori culture studies seperti yang sudah dipaparkan diawal tentang defenisidefenisi menurut para ahli.

Para pendiri cultural studies mempunyai latar belakang pendidikan Sastra, dapat dilihat dari segi perkembangan strukturalisme dalam kritik-kritik Sastra yang berkembang pesat di Eropa pada masa itu. Cultural Studies adalah studi kebudayaan atas praktek signifikasi representasi, dengan memperlihatkan pembentukan makna pada beragam konteks.

Novel tarian Bumi menggambarkan keadaan masyarakat Bali dengan berbagai probelm sosial dan aturan adat yang harus dipatuhi. Novel ini menceritakan para tokoh wanita yang mencoba memperjuangkan nasib mereka dengan menentang adat. Penentangan ini datang dari berbagai bentuk, salah satunya adalah pernikahan yang berbeda kasta yang dilakukan oleh Ida Ayu Telaga Pidada yang berasal dari kasta brahmana dengan Wayan Sasmitha yang berasal dari kasta sudra.

Fokus pada kajian budaya peneliti sudah mengutip salah satu contoh budaya lazim yang ada pada novel Tarian Bumi yang kerapkali kita jumpai dalam kehidupan masyarakat sehari-hari.

"setelah disunting secara sah oleh Ida Bagus Ngurah Pidada, Luh Sekar tidak hanya harus meninggalkan keluarga dan kebiasaan-kebiasaannya. Selain berganti nama menjadi Jero Kenanga, dia harus juga meninggalkan semua yang pernah membesarkannya. Rasa sakit pertama yang harus ditanggungnya, dia tak lagi bisa memakai nama Ni Luh Sekar. Dia harus membiasakan diri dengan nama baru, Jero Kenanga" (Hal:54-55). 


\section{METODE PENELITIAN}

Jenis penelitian ini termasuk penelitian kualitatif. Menurut Moleong (2007:7), penelitian kualitatif adalah penelitian yang bermaksud untuk memahami gejala yang dialami oleh subjek penelitian misalnya presepsi, prilaku, motivasi, tindakan dan lain-lain Perbedaannya dengan penelitian kuantitatif adalah penelitian penelitian dari data, memanfaatkan teori yang ada sebagai bahan penjelas dan diakhiri dengan sebuah teori.

Metode yang digunakan dalam penelitian ini adalah metode deskriptif. Penelitian deskriptif adalah penelitian yang bertujuan untuk memberikan gambaran secara terarah atau teratur tentang kondisi/situasi, permasalahan, fenomena, layanan atau program informasi. Seperti kondisi kehidupan suatu masyarakat pada suatu daerah, tata cara yang berlaku dalam masyarakat serta sikap, situasi-situasi, pandangan, proses yang sedang berlangsung, pengaruh dari suatu fenomena, pengukuran teliti tentang fenomena dalam masyarakat (Widi: 2010:47-48).

Data yang dikumpulkan dalam penelitian ini berupa kata-kata, kalimat dan wacana ataupun kutipan yang mengandung culture studies pada novel Tarian Bumi karya Oka Rusmini. Tentu saja sumber datanya dari novel Tarian Bumi karya Oka Rusmini yang diterbitkan oleh: PT Gramedia Pustaka Utama. Novel ini dicetak sebanyak tiga kali, cetakan pertama: Juli 2007, cetakan kedua: Juni 2013, cetakan ketiga: Maret 2017. Novel ini memiliki 176 halaman.

Prosedur pengumpulan data pengumpulan data melalui beberapa tahan yakni, membaca keseluruhan isi teks novel, mencatat setiap kutipankutipan agar jelas dan sesuai permasalahan yang diteliti, mengkasifikasi data yang telah dikumpulkan untuk mempermudah proses analisis data, mengidentifikasi permasalahn yang ada dalam novel dan menyimpan data yang diperoleh.

Prosedur penganalisisan data juga melalui beberapa tahap yakni, mencermati kembali data yang di kumpulkan, mengklasifikasi data yang ditemukan, melakukan interpritasi terhadap data yang ditemukan, menyimpulkan data.

Pemeriksaan teori dilakukan dengan melihat teori-teori yang berkaitan dengan kajian budaya dengan pendekatan culture studies. Diteliti dan dicocokan dengan hasil penelitian.

Pemeriksaan metode dilakukan dengan cara pengecekan pada langkah pengumpulan data juga saat melakukan penganalisisan data. Dengan melakukan pemeriksaan data dan pemeriksaan teori diperoleh yang valid.

Teknik yang digunakan dalam penelitian ini adalah teknik triangulasi data dan sumber data.

Teknik yang digunakan dalam penelitian ini adalah teknik triangulasi data dan sumber data.

Artinya peneliti membandingkan data berupa kata, frasa, atau kalimat yang diperoleh ari sumber penelitian yaitu Novel Tarian Bumi karya Oka Rusmini.

\section{HASIL PENELITIAN DAN PEMBAHASAN}

Pada bagian ini, sudah dikumpulkan banyaknya data dengan menggunakan metode kualitatif. Dalam menganalisi data-data tersebut, peneliti menggunakan teori culture studies oleh Taylor sehingga 
menghasilkan data yang valid sesuai dengan rumusan masalah yang dikaji pada novel Tarian Bumi. Hasil dari penelitian tersebut diperoleh nilainilai kebudayaan yakni, kepercayaan, moral dan adat-istiadat.

\section{Kepercayaan}

Mempunyai kepercayaan sama halnya mempercayai atau memiliki komitmen pada sesuatu atau sesorang. Konsep kepercayaan mempunyai dua pengertian. Pertama kepercayaan dijeaskan sebagai kultur atau budaya dan lembaga keagmaan seperti Islam, Kristen, Budha, Hindu, Katolik dan lain-lainnya.

Berikut kutipan yang menggambarkan nilai kepercayaan dalam novel Tarian Bumi.

"Ya. Sayang sekali para dewa pilih kasih. Kenapa hanya perempuan bangsawan yang diberi seluruh kecantikan Bumi!” (Rusmini, 2017:9) Kutipan tersebut kembali menjelaskan tentang bagaimana dewa dipercayai pilih kasih terhadap perempuan Brahmana, karena diberi kecantikan yang sangat istimewa dari segi paras dan penampilan. Terlihat bahwa pandangan umum perempuan Brahmana memang diwarisi kecantikan yang berebeda dengan perempuan biasa lainnya.

Nilai kepercayaan pada kutipan tersebut merupakan bentuk hubungan interpersonal yakni hubungan antara orang lain dan lingkungan. Terbukti lewat pandangan umum yang selalu mempercayai kecantikan itu hanya miliki bangsa Brahmana.

\section{Moral}

Nilai moral merupakan nilai yang berkaitan dengan perbuatan baik serta buruk yang dijadikan pedoman kehidupan secara umum. Berikut contoh kutipan yang menggambarkan nilai moral dalam novel Tarian Bumi.

"Kau tak pernah bisa memberi kebahagiaan pada anakku, Kenanga!" Suara nenek terdengar getir dan amat menusuk. Ibu hanya bisa diam sambil menelan tangisnya dalam-dalam. (Rusmini, 2017:13)

Kutipan tersebut menjelaskan karakter Nenek yang sangat membenci menantunya, yakni Kenanga. Dia selalu melontarkan caci maki kepada menantunya itu, setiap keburukan yang dilakukan anak lakiklakinya itu dia menganggap Kenanga lah yang menjadi kunci semuanya itu terjadi. Nenek ini adalah perempuan yang keras, dia tidak pernah melihat sisi baik dari menantunya walupun secuil, yang ada hanya kebencian yang luar biasa. Jika dilihat dari keseluruhan isi novel Tarian Bumi, tokoh Nenek adalah bangsawan Brahmana yang konon dia adalah seorang putri yang memiliki keagungan dan penuh cinta karean dibesarkan dari keluarga yang baik. Tapi setelah dia menjadi seorang Nenek bahkan semenjak anaknya Menikah dia seperti sosok yang sangat kejam lewat caci maki yang selalu dilontarkan pada menantunya. Seperti tidak pernah adanya nilai cinta kasih yang orang tua tanamkan pada diri Nenek. Disini terlihat nilai moral Nenek kurang dibentuk sehingga dia selalu berkata kasar pada orang lain yakni menantunya.

\section{Adat-istiadat}

Adat-istiadat merupakan nilai yang selalu hidup yang berdampingan dengan kehidupan sosial dalam masyarakat. Adat memiliki nilai yang sangat kental dan ada hukum yang terikat. Berikut contoh kutipan 
tentang adat-istiadat dalam novel Tarian Bumi.

kawin dengan seorang perempuan yang telah dijadikan sentana (ahli waris). Yang perempuan berkuasa di rumah. Dalam hal yang demikian pihak perempuan yang meminta lakilaki. Karena peraturan adat dibalikan, maka pihak perempuan dipandang sebagai laki-laki yang lelaki sebagai perempuan. (Rusmini, 2017:15)

Kutipan tersebut merupakan kajian budaya(culture studies) yang bernilai adat-istiadat. Pada kutipan ini dijelaskan bahwa sudah menjadi adat apabila laki-laki Sudra menikah dengan perempuan Brahmana maka statusnya akan berubah. Ini dikarenakan peraturan adat yang dibalikan. Jadi di dalam rumah perempuan yang lebih berkuasa dari pada laki-laki. Pada kutipan ini menggambarkan suatu aturan adat, yang sudah menjadi aturan dari nenek moyang. Nilai adat ini memang tidak tertulis tetapi keberadaanya ada dan hukmannya mutlak.

\section{PEMEBAHASAN}

\section{Kepercayaan}

Sesuai dengan hasil penelitian mengkaji kebudayaan pada novel Tarian Bumi dengan menggunakan teori Tylor, maka hasil penelitian tersebut menarik tiga nilai yang tergambarkan dalam kebudayaan yakni, Kepercayaan, Moral dan Adatistiadat. Pada hasil penelitian novel Tarian Bumi, dinyatakan bahwa nilai kepercayaan itu ada dan sangat sakral. Kepercayaan pada diri sendiri, lingkungan dan kepercayaan kepada dewa-dewa yang sangat nampak dalam novel Tarian Bumi. Pada novel tersebut menjelaskan betapa besar kuasa para dewa, karena atas kuasa dan izinnya segala sesuatu yang baik nan indah itu dapat dilihat dengan kasat mata.

\section{Moral}

Nilai moral yang digambarkan pada novel Tarian Bumi, dilihat dari jenisnya, Nilai moral memiliki dua jenis yakni, nilai moral baik dan nilai moral buruk. Nilai moral baik terkait dengan rekonsilisasi tujuan dan harapan hidup manusia. Dapat dilihat dari aturan sosial mana yang baik dan mana yang buruk. Nilai moral tersebut dapat ditinjau dari tindak tutur, perilaku setiap tokoh. Misalnya, nilai moral yang terdapat pada ibu Telaga yaitu Sekar, dia tidak pernah mau melawan mertuanya sekalipun sering kali Nenek Telaga itu mencaci maki dirinya. Ini merupakan bentuk nilai moral yang baik, dibandingkan dengan kehidupan kita sehari-hari bahwa hal tersebut mengajarkan tentang bagaimana menghormati orang tua atau orang yang lebih tua dari kita.

\section{Adat-istiadat}

Hasil penelitian juga menemukan beberapa nilai adatistiadat yang terkandung novel Tarian Bumi.

Pada novel Tarian Bumi ditunjukan adanya adat yang menjadi suatu kebiasaan. Salah satu kebiasaan yang terdapat novel Tarian Bumi ialah mencerminkan tentang perjodohan. Seperti pada bangsawan Brahmana harus menikahkan anaknya dengan kerabat yang sama-sama golongan Brahmana. Tokoh Nenek pun tidak bisa menolak, selain sudah menjadi adat didalam keluarganya, dia juga harus menerima perjodohan itu karena dia satu-satunya turunan yang dimiliki. Dan orang tuanya berharap agar Tokoh Nenek ini kelak bisa mengurus orang tuanya. Dapat 
ditinjau bahwa pada Novel Tariaan Bumi adat-istiadat tidak bisa ditentang, karena adanya hukuman yang mutlak.

Dibandingkan dengan kehidupan sekarang, masih banyak kelompok masyarakat yang seperti bangsa Brahmana, menginginkan perjodohan dengan kelompok yang dianggap memiliki derajat yang sama. Tanpa melihat perubahan zaman, bagi kelompok tertentu semua tetap tidak sama, tetap adanya perbedaan status sosial dalam masyarakat.

Penelitian saya berbeda dengan penelitian yang dilakukan oleh Rany Mandrastuty, walaupun objek penelitiannya sama yaitu novel Tarian Bumi. Pada penelitian Rany, dia menggunakan kajian Feminisme. Peneliti menafsirkan tentang unsurunsur strukturak, figur tokoh perempuan, dan bagaimana perjuangan tokoh perempuan dalam mewujudkan atau menghidupkan nilai feminisme. Perjuangan tokoh perempuan dalam mewujudkan feminisme menggambarkan tentang pembrontakan atau perlawanan perempuan bali terhadap praktikprakti budaya yang menindas dengan caranya sendiri.

Sedangkan penelitian saya menggunakan teori culture studies dalam mengkaji kebudayaan. Kebudayaan tersebut memiliki 3 nilai yakni Nilai Kepercayaan, Moral dan Adat Istiadat. Ketiga nilai tersebut sangat digambarkan dalam novel Tarian Bumi dimana semuanya memberikan pelajaran atau pengetahuan tetang tatanan sosial dalam kehidupan bersmasyarakat atau berkelompok. Selain itu memberi wawasan luas tetang ritual-ritual adat yang perlu dilakukan sebagai ungkapan terima kasih atau syukur kepada Empunya kehidupan.

\section{SIMPULAN}

Berdasarkan hasil penelitian
dengan menggunakan metode kualitatif berhasil menggumpulkan data-data yang berkaitan dengan rumusan masalah yang tertujuh pada tiga nilai kebudayaan yaitu kepercayaan, moral dan adat-istiadat. Dari data-data tersebut peneliti menarik kesimpulan sebagai berikut.

Nilai Kepercayaan

Disimpulkan bahwa pada novel Tarian Bumi terdapat nilai Keperecayaan yang sangat besar tehadap Tuhan, lingkungan dan kepercayaan yang lahir dari diri sendiri.

Nilai Moral

Nilai moral yang disampaikan dalam novel ini sangat digambarkan melalui karakter tokoh maing-masing, ada yang bernilai moral baik dan ada pula yang bernilai moral buruk.

Nilai Adat-istiadat

Adat istiadat yang ada pada novel Tarian Bumi merupakan suatu aturan yang sangat patut di hargai dengan cara mengikuti semua aturan yang sudah ditetapkan oleh aturan adat itu sendiri.

\section{SARAN}

Berdasarkan hasil penelitian, ada beberapa hal yang dapat disarankan:

1. Penelitian yang berkaitan dengan kebudayaan bisa menggunakan teori culture studies sebagai acuan dalam meneliti novel-novel lainnya.

2. Hasil penelitian ini dapat menjadi salah satu refrensi tambahan bagi penelitian karya sastra dan menambah wawasan serta pengetahuan kepada pembaca tentang kajian budaya.

3. Diharpakan hasil penelitian ini menjadi bahan perbandingan dan 
pertimbangan penelitian sastra Indonesia serta dijaddikan dasar penelitian lanjut.

\section{DAFTAR PUSTAKA}

Azmy, Bahauddin. Agung Pramujiono., dan Pana Pramulia. 2017. Bahasa dan sastra Indonesia: Teori dan Paradigma Bahasa dan Sastra Indonesia untuk PGSD, Surabaya: Adi Buana University Press.

Departemen Pendidikan Nasional. 2008. Kamus Besar Bahasa Indonesia Jakarta:

PT.Gramedia Pustaka Utama.

Mandrastuty Rani 2010, Novel Tarian Bumi Karya Oka Rusmini: Kajian Feminisme.

Matthew B. Miles and A. Michael Huberman. 1992. Analisis

Data Kualitatif. Jakarta: UI Press.

Moleong, L J. (2004). Metodologi Penelitian Kualitatif. Bandung: $\quad$ PT.Remaja Rosdakarya.

Sugiyono. 2005. Memahami Penelitian Kualitatif. Bandung: CV. Alfabeta. 